Research Report No. 12/2009

\title{
Shareholder Engagement in the Embedded Business Corporation: Investment Activism, Human Rights and TWAIL Discourse
}

Aaron A. Dhir

Osgoode Hall Law School of York University, adhir@osgoode.yorku.ca

Follow this and additional works at: http://digitalcommons.osgoode.yorku.ca/clpe

\section{Recommended Citation}

Dhir, Aaron A., "Shareholder Engagement in the Embedded Business Corporation: Investment Activism, Human Rights and TWAIL Discourse" (2009). Comparative Research in Law \& Political Economy. Research Paper No. 12/2009.

http://digitalcommons.osgoode.yorku.ca/clpe/127 


\section{Aaron A. Dhir}

Shareholder Engagement in the Embedded Business Corporation: Investment Activism, Human Rights and TWAIL Discourse

EDTORS: Peer Zumbansen (Osgoode Hall Law School, Toronto, Director, Comparative Research in Law and Political Economy, York University), J ohn W. Cioffi (University of California at Riverside), Nassim Nasser (Osgoode Hall Law School, Toronto, Production Editor) 

CLPE Research Paper 12/2009

Vol. 05 No. 02 (2009)

\title{
Aaron A. Dhir \\ SHAREHOLDER ENGAGEMENT IN THE EMBEDDED BUSINESS CORPORATION: InVESTMENT ACTIVISM, HuMAN RightS AND TWAIL Discourse
}

\begin{abstract}
The expansion of Canadian extractive corporations' overseas business operations has led to serious concerns regarding human rights-related impacts. As these apprehensions grow, we see a countervailing rise in calls for government intervention and in levels of socially conscious shareholder advocacy. I focus on the latter as manifested in recent use of the shareholder proposal mechanism found in Canadian corporate law. Shareholder proposals, while under-theorized, provide a valuable lens through which to consider the argument that economic behaviour is embedded within social relations. In doing so, I situate my analysis within Third World Approaches to International Law (TWAIL) scholarship. Elsewhere, I have supported the use of corporate law tools in advancing the international human rights enterprise and argued that investment activism can be an essential component of this advancement. This chapter represents a reflexive pause. I seek to problematize the shareholder proposal as a human rights advocacy tool and to examine it as a site of contestation.
\end{abstract}

Keywords: Corporate law, shareholder rights, corporate accountability, Third World Approaches to International Law

JEL classification: K22, K33

\author{
Aaron A. Dhir \\ Assistant Professor \\ Osgoode Hall Law School, York University, Toronto. \\ Email: adhir@osgoode.yorku.ca
}




\title{
Shareholder Engagement in the Embedded Business Corporation: Investment Activism, Human Rights and TWAIL Discourse
}

\author{
Aaron A. Dhir* \\ Forthcoming in Peer Zumbansen \& Cynthia Williams (eds.) \\ The Embedded Firm: Labour, Corporate Governance and Finance Capitalism (2010)
}

\section{INTRODUCTION}

The present section of this text is aptly titled "New Interests, New Shareholder Constellations, New Landscapes". As interests, arrangements and landscapes are constantly formed and reformed in the contemporary business corporation, another manifestation of newness becomes apparent - new tensions.

In various respects, tension serves as a key motif in the work of Karl Polanyi, whose famous concept of "embeddedness" informs the chapters in this collection. ${ }^{1}$ Polanyi illustrates the existence of society and the market in a state of "related tension". The latter is embedded within the former and in order to protect against the risks that follow self-interested gain, "market societies must construct elaborate rules and institutional structures". 3 This engages the "double movement" thesis. As the negative consequences of economic activity become more pronounced, protective reactions are catalyzed that seek to resist efforts to decontextualize the economy from societal institutions. ${ }^{4}$ Block discusses these themes by invoking the image of a rubber band. Attempts to enhance market sovereignty raise the degree of tension as the band is

\footnotetext{
* Assistant Professor, Osgoode Hall Law School of York University. I wish to express my thanks to Obi Okafor, Sara Seck, Catherine Coumans and Michael Fakhri and to acknowledge, with appreciation, the research assistance of Jessica DiFederico and the editorial assistance of Chad Travis.

${ }^{1}$ While Polanyi's seminal text - "The Great Transformation" - did not explicitly accentuate this idea, it firmly planted the conceptual seeds. See Karl Polanyi, The Great Transformation: The Political and Economic Origins of Our Time (Boston: Beacon Press, 1944) at 68 (“...never before our own time were markets more than accessories of economic life. As a rule the economic system was absorbed in the social system..."). See also Bernard Barber, "All Economies are "Embedded": The Career of a Concept, and Beyond" (1995) 62 Social Research 387 at 401 and Fred Block, "Karl Polanyi and the Writing of The Great Transformation" (2003) 32 Theory and Society 275 at 276.

2 Mark Banks, "Karl Polanyi, The Rubberband Man" (12 December 2008), online: http://www.open2.net/blogs/society/index.php/2008/12/12/karl-polanyi-the-rubberband-man?blog=10

${ }^{3}$ Block, supra note 1 at 297.

${ }^{4}$ Polanyi, supra note 1 at 76 ("While on the one hand markets spread all over the face of the globe...on the other hand a network of measures and policies was integrated into powerful institutions designed to check the action of the market...Society protected itself against the perils inherent in a self-regulating market system...").
} 
stretched. As this elongation continues, the band will eventually break (i.e. social dissolution) or retract (i.e. the market will go back to an embedded state). ${ }^{5}$

At its core, this analytical structure is concerned with the state necessarily imposing a regulatory and institutional framework that constricts unbridled market movements, thereby docking the market in the "moral fabric of society." This approach has obvious applicability to contemporary debates surrounding globalization, deregulation and the global financial crisis. In this chapter, I explore another issue of current importance. The expansion of Canadian extractive corporations' overseas business operations has led to concerns regarding human rights-related impacts. As these apprehensions grow, we see a countervailing rise in calls for government intervention ${ }^{7}$ and in levels of socially conscious shareholder advocacy.

I focus on the latter as manifested in recent use of the shareholder proposal mechanism found in Canadian corporate law. Shareholder proposals, while under-theorized, provide a valuable lens through which to consider the argument that economic behaviour is embedded within social relations. In doing so, I situate my analysis within Third World Approaches to International Law (TWAIL) scholarship. ${ }^{8}$ Indeed, it seems particularly fitting to establish linkages between the concept of "embeddedness" and TWAIL literature given Polanyi's seething indictment of the colonial encounter and his contention that the forced adoption of market economies led to the "rapid and violent disruption of the basic institutions" of the Third World. ${ }^{9}$

Elsewhere, I have supported the use of corporate law tools in advancing the international human rights enterprise and argued that investment activism can be an essential component of

\footnotetext{
${ }^{5}$ Fred Block, "Introduction" in Karl Polanyi, The Great Transformation: The Political and Economic Origins of Our Time, $2^{\text {nd }}$ ed. (Boston: Beacon Press, 2001) at xxv.

${ }^{6}$ Jens Beckert, "The Great Transformation of Embeddedness: Karl Polanyi and the New Economic Sociology" (2007) MPIfG Discussion Paper 07/1 at 8, online:

$<$ http://www.mpifg.de/pu/mpifg_dp/dp07-1.pdf $>$.

${ }^{7}$ See, for example, Bill C-300, Corporate Accountability of Mining, Oil and Gas Corporations in Developing Countries Act, 2nd Session, 40th Parliament, 57-58 Elizabeth II (2009), online:

$<$ http://www2.parl.gc.ca/HousePublications/Publication.aspx?DocId=3658424\&Language $=\mathrm{e} \&$ Mode $=1 \&$ File $=24 \# 1$

$>$.

${ }^{8}$ The use of the term "Third World" in this context is meant to include "the group of states and peoples who "selfidentify' as such." See O.C. Okafor, "Marxian Embraces and De-couplings in Upendra Baxi's Human Rights Scholarship: A Case Study" in S. Marks, ed., International Law on the Left (Cambridge: Cambridge University Press, 2008) at 253, n. 4.

${ }^{9}$ Polanyi, supra note 1 at 159 . For more on this point, see M. Fakhri, "Law as the Interplay of Ideas, Institutions, and Interests: Using Polyani (and Foucault) to ask TWAIL Questions" (2008) 10 International Community Law Review 455 at $460-461$.
} 
this advancement. ${ }^{10}$ This chapter represents a reflexive pause. I seek to problematize the shareholder proposal as a human rights advocacy tool and to examine it as a site of contestation.

\section{OVerview OF THE Proposal Structure}

The shareholder proposal structure in corporate law provides equity holders with the ability to compel management to hold a shareholder vote on issues the proponent considers salient. Shareholder-commenced proposals are a novel implement in the overall corporate law tool shed, as they allow the investor to trigger activity and investor-to-firm dialogue, rather than passively absorbing the actions of management. The proposal mechanism is not meant to appropriate management's authority, but to "provide shareholders with the opportunity to express their views on issues affecting their corporation..." and to allow them "to hold management accountable for its actions and to influence future business decisions by having a public forum in which to challenge management." 12 In terms of procedure, the firm is obligated to include a proposal in the management proxy circular materials. ${ }^{13}$ Shareholders then consider the proposal before a vote at an annual or special meeting.

The company, however, is excused from the requirement to circulate a proposal if a substantive ground for exclusion is present or if particular procedural requirements are not adhered to. ${ }^{14}$ In the U.S., recent developments indicate a regulatory momentum towards curbing shareholder rights of expression. ${ }^{15}$ The Canadian experience has been quite different. In 2001, the Canada Business Corporations Act (CBCA) underwent substantial revision. Of particular relevance is an amendment that altered when the firm can lawfully refuse to circulate a proposal on substantive grounds. Prior to 2001, the law allowed exclusion if the proposal was submitted

\footnotetext{
${ }^{10}$ Aaron A. Dhir, "Realigning the Corporate Building Blocks: Shareholder Proposals as a Vehicle for Achieving Corporate Social and Human Rights Accountability" (2006) 43:2 American Business Law Journal 365 [Dhir, "Realigning"], Aaron A. Dhir, "The Politics of Knowledge Dissemination: Corporate Reporting, Shareholder Voice and Human Rights" forthcoming in (2009) 47 Osgoode Hall Law Journal 1 [Dhir, "The Politics"].

${ }^{11}$ Thomas A. DeCapo, "Challenging Objectionable Animal Treatment with the Shareholder Proxy Proposal Rule" (1988) University of Illinois Law Review 119 at 138.

${ }^{12}$ Ibid. at 138 - 39. The proposal mechanism is an alternative to simply raising an issue from the meeting floor, which "often gets a nonresponsive reply...[and] [e]ven if [the shareholder's] question is answered...his efforts will generate as much noise as a tree falling in an uninhabited forest." See Donald E. Schwartz \& Elliott J. Weiss, "An Assessment of the SEC Shareholder Proposal Rule" (1977) 65 Georgetown Law Journal 635 at 641.

${ }^{13}$ Canada Business Corporations Act, R.S. 1985, c. C-44, ss. 137(2).

${ }^{14}$ Dhir, "Realigning", supra note 10 at $385-390$.

${ }^{15}$ See the recent "Save Shareholder Rights" Campaign, a joint initiative of the Social Investment Forum and the Interfaith Center on Corporate Responsibility, which sought to prevent various regulatory changes proposed by the U.S. Securities and Exchange Commission in "Shareholder Proposals", 17 C.F.R. Part 240 (27 July 2007), online: $<$ http://www.sec.gov/rules/proposed/2007/34-56160.pdf $>$.
} 
"by the shareholder primarily for the purpose of...promoting general economic, political, racial, religious, social or similar causes." 16 Under the new test, exclusion is permitted where it "clearly appears that the proposal does not relate in a significant way to the business or affairs of the corporation." 17

The post-amendment period has seen a marked increase in use of the proposal mechanism with respect to issues of corporate governance and human rights/environmental/social policy. ${ }^{18}$ Taking the latter as an example, in 2001 - the year of the amendments - just two social responsibility-related shareholder proposals were submitted to Canadian firms. ${ }^{19}$ This was the case again in 2002. ${ }^{20}$ However, from 2003 - 2006, the numbers increased to thirteen, ${ }^{21}$ eleven, ${ }^{22}$ twenty-five ${ }^{23}$ and twenty-eight. ${ }^{24}$ In the 2007 and 2008 proxy seasons, there was a striking spike in the use of proposals as a means of advancing human rights issues. My analysis of data compiled by the Shareholder Association for Research and Education reveals that in these years investors submitted approximately forty-six and forty-two proposals, respectively, to Canadian firms. The general upward rise can be represented approximately as follows:

${ }^{16}$ CBCA, supra note 13 (prior to the 2001 amendments).

${ }^{17}$ CBCA, supra note 13 , ss. 137(5)(b.1).

${ }^{18}$ This trend has occurred in other jurisdictions as well. See T. Guay, J. Doh \& G. Sinclair, "Non-Governmental Organizations, Shareholder Activism, and Socially Responsible Investments: Ethical, Strategic, and Governance Implications" (2004) 52 Journal of Business Ethics 125.

${ }^{19}$ Benjamin J. Richardson, "Financing Environmental Change: A New Role for Canadian Environmental Law" (2004) 49 McGill Law Journal 145 at 183.

${ }^{20}$ Social Investment Organization, "Canadian Social and Environmental Resolutions Reach 13 This Year, Up from Two in 2002", online:

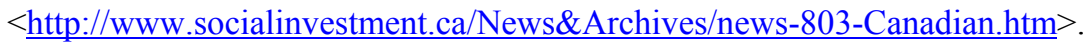

${ }^{21}$ Ibid.

${ }^{22}$ Social Investment Organization, "Socially Responsible Shareholder Proposals Double in 2005; Climate Change, Human Rights Leading Issues", online:

$<$ www.socialinvestment.ca/News\&Archives/news-305-ShareholderProposals.htm>.

${ }^{23}$ Ibid.

${ }^{24}$ Social Investment Organization, "Canadian SRI Investors File 28 Social and Environmental Shareholder Proposals with Canadian Firms", online:

$<\underline{w w w . s o c i a l i n v e s t m e n t . c a / N e w s \& A r c h i v e s / n e w s-0306-S h a r e h o l d e r p r o p o s a l s . h t m>. ~}$ 


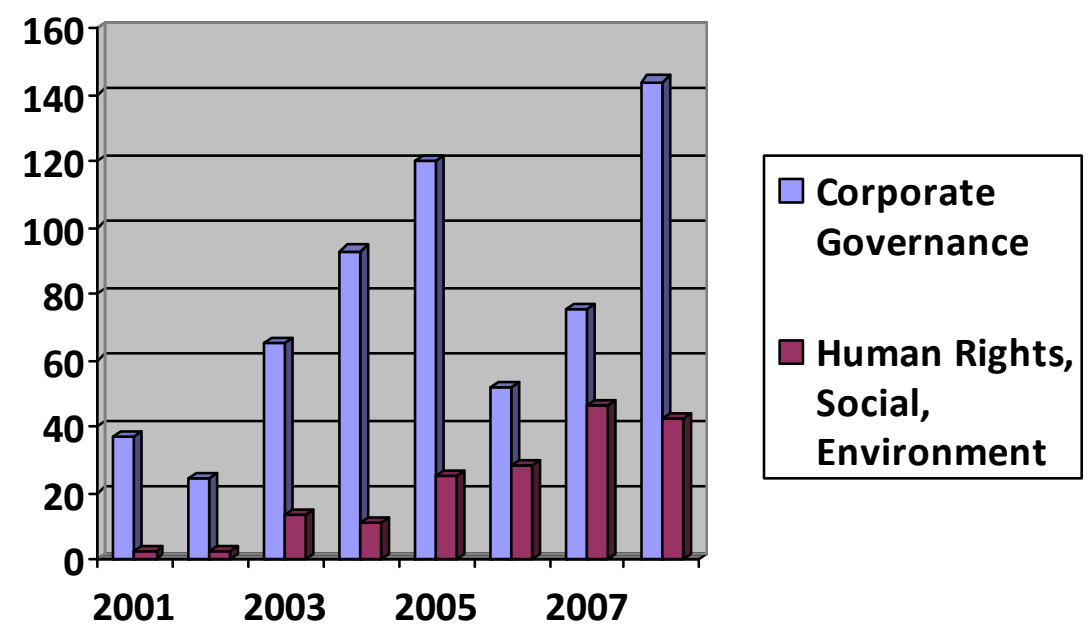

Human rights in Burma, ${ }^{25}$ human rights in China, ${ }^{26}$ aboriginal land claims, ${ }^{27}$ gender diversity, ${ }^{28}$ biodiversity protection, ${ }^{29}$ climate change risk and related disclosure ${ }^{30}$ - these are just some of the topical issues that have been broached in Canadian shareholder resolutions. Should this trend of using the corporation as an arena for political discourse be viewed in a positive or negative light? The answer, of course, depends on the perspective from which we consider the issue. For economic theorists, the very existence of the proposal mechanism is a peculiarity. As Professor Lee observes:

...for many opponents of social shareholder proposals, the shareholder proposal mechanism itself (never mind proposals directed at social responsibility) seems anomalous. For one thing, the mechanism is in tension with the separation of ownership and control, which economic theorists of the corporation believe

25 Shareholder Association for Research and Education, "Shareholder Resolution Database", online: $<$ http://www.share.ca/en/node/1368 $>$.

26 Shareholder Association for Research and Education, "Shareholder Resolution Database", online: < http://share.ca/en/node/888>.

27 Shareholder Association for Research and Education, "Shareholder Resolution Database", online: $<$ http://www.share.ca/en/node/587> .

28 Shareholder Association for Research and Education, "Shareholder Resolution Database", online: < http://share.ca/en/node/483>.

29 Shareholder Association for Research and Education, "Shareholder Resolution Database", online: < http://share.ca/en/node/868>.

30 Shareholder Association for Research and Education, "Shareholder Resolution Database", online:

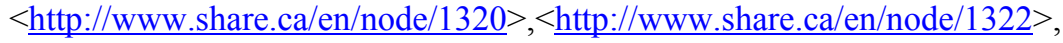

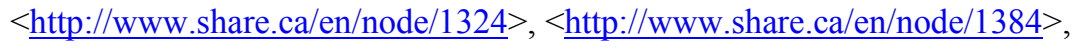

$<$ http://www.share.ca/en/node/1386 $>$ and $<$ http://www.share.ca/en/node/1389>. 
produces gains through the specialization of functions. Moreover, shareholders have no reason to vote on a shareholder proposal, or for that matter any other matter submitted to shareholders, since they rationally have no expectation that their vote will be pivotal. For both of these reasons, economic theorists of the corporation typically have difficulty accounting for the existence of a shareholder proposal mechanism. ${ }^{31}$

Beyond academic puzzlement, particular commentators view proposals as a tool used "chiefly by time-worn gadflies... unable to achieve their ends through legitimate political mechanisms" ${ }^{\prime 32}$ that threaten to "lead management to be less inclined to pursue shareholder wealth maximization..."33 Correspondingly, some have called for the abolition of the mechanism. ${ }^{34}$

If, however, we view the proposal structure in light of social movement theory, we find a different set of considerations at play. While the study of social movement activity has typically been preoccupied with the public realm, scholars of late have turned their attention to the private, analyzing the relationship between social mobilization and corporate operations. ${ }^{35}$ In particular, the literature reveals an increasing interest in how strategically focused activism informs organizational development. ${ }^{36}$ Den Hond and DeBakker note that reformative activist groups seeking to influence the levels and content of corporate social responsibility may prefer to rely on participatory modes of engagement in attempting to gain leverage over targeted businesses. ${ }^{37}$ In doing so, such groups must position their issues in a manner that clearly demonstrates their value and relevance to the firm in question. This may be accomplished through illustrating the

${ }^{31}$ Ian Lee, "Corporate Law, Profit Maximization and the 'Responsible' Shareholder" (2005) 10 Stanford Journal of Law, Business \& Finance 31 at $63-64$ (citations omitted).

${ }^{32}$ George W. Dent, Jr., "Proxy Regulation in Search of a Purpose: A Reply to Professor Ryan" (1989) 23 Georgia Law Review 815 at 820 . See also David Vogel, Lobbying the Corporation: Citizen Challenges to Business Authority (New York: Basic Books, 1978) at 208ff.

${ }^{33}$ Alan R. Palmiter, "The Shareholder Proposal Rule: A Failed Experiment in Merit Regulation" (1993) 45 Alabama Law Review 879 at 899 . See also Roberta Romano, "Less is More: Making Institutional Investor Activism a Valuable Mechanism of Corporate Governance" (2001) 18 Yale Journal on Regulation 174 at 186, n. 30 ("Social responsibility proposals are not a focus of this article because they are not advanced in order to improve corporate performance and are consequently, not compatible with the objective of U.S. corporate law, which is to maximize share value.") and Henry G. Manne, "Shareholder Social Proposals Viewed by an Opponent" (1972) 24 Stanford Law Review 481.

${ }^{34}$ Susan W. Liebeler, "A Proposal to Rescind the Shareholder Proposal Rule" (1984) 18 Georgia Law Review 425 at $426-427$ ("[b]ecause it is an unwise and unwarranted intrusion into private transactions, private markets, and state corporation law, the rule should be rescinded").

${ }^{35}$ Erin Marie Reid \& Michael W. Toffel, "Responding to Public and Private Politics: Corporate Disclosure of Climate Change Strategies" (18 August 2008) at 8, online:

$<$ http://papers.ssrn.com/sol3/papers.cfm?abstract_id=1237982 > (citations omitted).

${ }^{36}$ Ibid. at 9 (citations omitted).

${ }^{37}$ Frank Den Hond \& Frank G. A. DeBakker, "Ideologically Motivated Activism: How Activist Groups Influence Corporate Social Change Activities" (2007) 32:3 Academy of Management Review 901 at 911. 
potential for "material and symbolic gain"; in other words, through establishing pecuniary advantage or the possibility of enhanced reputational capital. ${ }^{38}$ I will return to this idea in more detail below.

\section{THE IMPACT OF SHAREHOLDER PROPOSALS}

When considering shareholder proposals as part of a rights-based advocacy strategy, it is important to note the dialogue that arises between investors and corporate management. The former's concerns are expressed to management via the proposal's submission. This should be viewed less as an adversarial expression and more as the initiation of a conversation on issues of mutual concern.

While arguably a "lower profile tactic" 39 , proposals have the potential to yield enormous gains for the proponent. There is accumulating evidence "suggest[ing] that today's proposals may become tomorrow's corporate policy". ${ }^{40}$ In other words, through the submission process, and the resulting dialogue between the investor and the firm, the formulation of corporate policy relating to human rights issues has been transformed. ${ }^{41}$ In certain cases, investors have withdrawn proposals after conducting successful negotiations with management. I have previously canvassed several examples of this trend, which I have viewed in a positive light. ${ }^{42}$ Another, more recent, proposal ${ }^{43}$ serves as a useful example of serious difficulties that arise when employing proposals in the human rights sphere; as such, this example merits unpacking.

In 2008, a consortium of investors ${ }^{44}$ submitted a proposal to Vancouver-based Goldcorp Inc. Goldcorp, one of the largest global gold mining companies, has received scathing critique

\footnotetext{
${ }^{38}$ Ibid. at 915.

${ }^{39}$ K. Rehbein, S. Waddock \& S.B. Graves, "Understanding Shareholder Activism: Which Corporations are Targeted?" (2004) 43 Business and Society 239 at 240.

${ }^{40}$ Janis Sarra, "Shareholders as Winners and Losers under the Amended Canada Business Corporations Act" (2003) 39 Canadian Business Law Journal 52 at $74-75$.

${ }^{41}$ See J.M. Logsdon \& H. J. Van Buren III, "Beyond the Proxy Vote: Dialogues between Shareholder Activists and Corporations" (2009) 87 Journal of Business Ethics 353 at 353 ("The phenomenon of Dialogue between a corporation and dissident shareholders has not been analyzed in the academic literature ...because it occurs behind the scenes ...Yet this is where a great deal of social change initiated by shareholder activists is negotiated").

${ }^{42}$ Dhir, "Realigning", supra note 10 at $405-407$.

${ }^{43}$ I have also considered this proposal favorably. Dhir, "The Politics", supra note 10 at $27-28$.

${ }^{44}$ The Public Service Alliance of Canada Staff Pension Fund, the Ethical Funds Company, the First Swedish National Pension Fund and the Fourth Swedish National Pension Fund.
} 
pertaining to the ecological and human rights impacts of its overseas operations. ${ }^{45}$ As a result of such concerns, Jantzi Research recently recommended that Goldcorp "be considered ineligible for [socially responsible investment] portfolios."46 The consortium requested that Goldcorp's Board commit to an independent human rights impact assessment of the firm's practices in Guatemala (in particular, with regard to the Marlin Mine in the western highlands). ${ }^{47}$ Human rights impact assessments are a relatively new tool that allow a firm "to systematically identify, predict and respond to the potential human rights impacts of a business project". ${ }^{48}$ The proposal was subsequently withdrawn after Goldcorp agreed to commission such an assessment. ${ }^{49}$

At one level, this development might be heralded as a milestone in corporate accountability engagement as it is unprecedented for a Canadian corporation to undertake an impact assessment focusing on human rights. ${ }^{50}$ This is particularly important in the context of the Canadian extractive industry. Canada has listed on its stock exchanges more mining firms than any other state. ${ }^{51}$ Globally, Canadian exchanges represent "the world's largest source of equity capital for mining exploration and production both in Canada and abroad." ${ }^{, 2}$ However, United Nations treaty monitoring bodies, academics, civil society groups and parliamentarians ${ }^{53}$ have all impugned the Canadian extractive sector for the deleterious human rights-related repercussions of its overseas operations.

\footnotetext{
${ }^{45}$ See, for example, Rights Action, "Investing in Conflict: Public Money, Private Gain - Goldcorp in the Americas" (2008), online: < http://www.rightsaction.org/Reports/research.pdf $>$ and Shin Imai, Ladan Mehranvar, \& Jennifer Sander, "Breaching Indigenous Law: Canadian Mining in Guatemala" (2007) 6 Indigenous Law Journal 101.

${ }^{46}$ Jantzi Research Client Alert, "Jantzi Research Recommends Goldcorp as Ineligible for SRI Portfolios" (30 April 2008) at 1.

${ }^{47}$ For recent accounts of local resistance to Goldcorp's operations in Guatemala, see Andy Hoffman, "Goldcorp Bested by Mayan Mother" The Globe and Mail (10 July 2008) B1 and Dawn Paley, "Goldcorp: Occupation and Resistance in Guatemala (and Beyond)" The Dominion (21 June 2008), online: The Dominion

$<$ http://www.dominionpaper.ca/weblogs/dawn/1887> .

${ }^{48}$ International Finance Corporation, "Guide to Human Rights Impact Assessment and Management - Executive Overview" (2007) at 5, online:

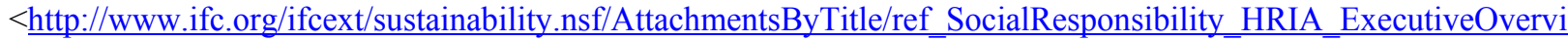
ew/\$FILE/HRIAexecsummary.pdf $>$.

49 Shareholder Association for Research and Education, "Shareholder Resolution Database", online: $<$ http://www.share.ca/en/node/1461>.

50 Investors Spur Goldcorp to Address Human Rights In Guatemala" (24 April 2008), online: $<$ www.newswire.ca/fr/releases/archive/April2008/24/c9323.html?view=print $>$.

${ }^{51}$ National Roundtables on Corporate Social Responsibility and the Canadian Extractive Industry in Developing Countries, "Advisory Group Report" (29 March 2007) at 3, online:

$<$ http://geo.international.gc.ca/cip-pic/library/Advisory\%20Group\%20Report\%20-\%20March\%202007.pdf $>$.

52 Ibid. For a discussion of the increased presence of Canadian mining firms in Latin America generally, see G. J. Munarriz, "Rhetoric and Reality: The World Bank Development Policies, Mining Corporations, and Indigenous Communities in Latin America" (2008) 10 International Community Law Review 431 at 440 (citations omitted).

${ }^{53}$ Dhir, "The Politics", supra note 10 at 6 (citations omitted).
} 
Further, beyond the end result of the impact assessment itself, there is value to be derived from the process of contemplating and selecting an assessment methodology. After the proposal's withdrawal, the consortium worked in concert with Goldcorp to design a procedure. ${ }^{54}$ The proposal's text also specifically references the assessment methodology created by Canadian organization Rights \& Democracy. ${ }^{55}$ Rights \& Democracy's impact assessment framework involves ten steps that include, for example, ascertaining the human rights context in the state that will host the proposed investment; seeking expert views on relevant human rights challenges; data collection, such as interviewing community members, government officials, corporate representatives and workers; the formulation of a draft report to be commented on by all relevant parties; establishing a set of conclusions and suitable corrective measures; and monitoring/continuing assessment. ${ }^{56}$ The process of appraising these sorts of methodologies and working through how they can best be integrated into business operations will undoubtedly be educative for corporate management and will assist it in developing a fluency in human rights concepts and techniques. ${ }^{57}$

That being said, there is also cause for very serious concern. After its inception, the consortium's proposal generated intense controversy. The controversy orginated not from detractors of the shareholder proposal mechanism or the business community; rather, it stemmed from Canadian human rights players and from Guatemalan communities. An early critique was advanced by non-governmental organization Rights Action:

While the original shareholder resolution may have been proposed with good intentions, we believe it will harm and undermine the clearly stated demands and positions of the Goldcorp-affected indigenous communities and may result in a whitewashing public relations exercise that only benefits Goldcorp and company shareholders and investors. ${ }^{58}$

MiningWatch Canada subsequently adopted and elaborated on the substance of these concerns. In a letter to the consortium and others MiningWatch wrote:

\footnotetext{
54 Shareholder Association for Research and Education, "Shareholder Engagement Activity Report Q1/08” at 6, online: International Alert to provide peer review. See CSRWire, "Human Rights Impact Assessment Contractors Selected and Website Established" (7 October 2008), online: < http://www.csrwire.com/News/13376.html>.

${ }^{58}$ Rights Action, “Open Letter from Rights Action to Goldcorp Inc. and Shareholders" (1 May 2008), online: $<$ www.rightsaction.org/articles/Goldcorp_Open\%20Letter_050108.html $>$.
} 
The shareholder proposal...reveals a lack understanding of the ethical responsibility to assure that shareholder resolutions that directly impact on locally affected communities do not undermine the efforts these communities are engaged in to protect their own rights. In short, shareholder resolutions put forward in Canada that will directly impact on local communities should have the free prior and informed consent of locally affected communities. ${ }^{59}$

The lack of locally affected communities' approval is arguably present at two levels; first, the drafting of the shareholder proposal itself and second, the drafting of the Memorandum of Understanding (MOU) entered into by the consortium and Goldcorp. ${ }^{60}$ With respect to the latter, MiningWatch notes the MOU does not permit a representative from communities on the ground to form part of the Steering Committee supervising the impact assessment process. As a result, unlike the foreign corporation and foreign investors, those whose rights are actually at stake and will be most impacted "have no direct role in setting the scope and the timelines of the assessment process, nor in selecting assessors and peer reviewers, nor in managing the assessment process." ${ }^{, 1}$ Affected communities in San Miguel Ixtahuacan referred to this asymmetry as "an act of racism and discrimination." 62

As use of the shareholder proposal mechanism by socially responsible investment organizations has increased in the post-CBCA amendment period, there has been a corresponding trend in affected communities viewing proposals submitted to Canadian extractive firms with apprehension. In addition to Goldcorp, other such instances include proposals submitted to Barrick Gold Corporation vis-à-vis its Pascua Lama mining project in Chile and to Alcan Inc. vis-à-vis its mining and refining project in Kashipur, India. ${ }^{63}$ At the heart of these examples is a tension that arises from potentially competing interests. I return to the idea of "material and symbolic gain" discussed above. The strategy of shareholder engagement entails the proposing group positioning the issue of concern as a matter of financial and reputational gain for the firm and of risk mitigation for the investor. With respect to the latter, Engle notes:

[C]orporations which violate human rights face higher insurance costs, lawsuits in tort and the risk of paying settlements or damages payments. Human rights abuse creates a riskier political climate which can cause rioting, leading to destruction of corporate property and the possible nationalization of business assets. Such risks

\footnotetext{
${ }^{59}$ Correspondence from Catherine Coumans, MiningWatch Canada to the consortium et. al. (4 December 2008) at

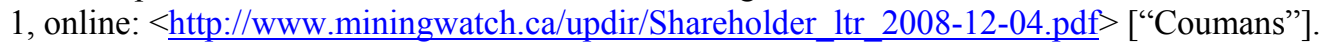

${ }^{60}$ Ibid. at $1-2$.

${ }^{61}$ Ibid. at 2.

${ }^{62}$ Correspondence from ADISMI, Parroquía de San Miguel Ixtahuacán, the Alcaldía del Pueblo and the Mam Maya communities in resistance (Ágel, San José Ixcaniche, Salitre) to the consortium et. al. (4 September 2008), online:

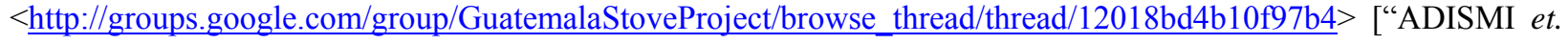
al."'].

${ }^{63}$ Coumans, supra note 59 at 2.
} 
are not just intolerable to individual investors; they also poison the capital market generally and discourage efficient capital formation. Companies which violate human rights laws risk investors' assets for questionable gains. They seek to externalize costs resulting in diseconomies to the detriment of the market. ${ }^{64}$

In fact, establishing a nexus between the subject matter of a human rights-related shareholder proposal and pecuniary advantage is not solely strategic but is arguably required in law. As discussed, the revised CBCA allows a shareholder proposal to be excluded where it "clearly appears that the proposal does not relate in a significant way to the business or affairs of the corporation." ${ }^{65}$ In my view, there is actually little difference between the current and preamendment tests. While the former removes the previously enumerated categories for exclusion (i.e. "general economic, political, racial, religious, social or similar causes"), the result, in essence, is the same. Previously, it had to be demonstrated that the proposal was not primarily for the purpose of promoting an enumerated cause; thus, by inference, that it was primarily submitted for a reason involving the business or affairs of the corporation. In other words, the amended formulation of the test would have to have been met under the previous test.

By way of illustration, in 2008 Goldcorp management relied on the "does not relate in a significant way to the business or affairs of the corporation" provision in refusing to circulate a proposal from a retail investor which asked the corporation to suspend any further mine expansion in the Guatemalan municipalities of San Miguel Ixtahuacan and Sipakapa without first obtaining the informed consent of local communities. ${ }^{66}$ Unlike the consortium's proposal, which specifically referenced "serious risks to shareholder value", 67 the retail investor's proposal made no mention of potential financial impact.

On its face, this may not seem problematic; it is logical that investors would want to assess and manage human rights-related financial risk and that a proposal to the corporation should be cast in those terms. However, when the subject of the proposal actually affects local communities (for example, it does not resonate with the agenda they are pursuing or it presents obstacles to their advocacy), ${ }^{68}$ the situation becomes more complex and two sets of conflicting interests emerge. This tension is eloquently articulated by the San Miguel Ixtahuacan communities:

\footnotetext{
${ }^{64}$ Eric Engle, "What You Don't Know Can Hurt You: Human Rights, Shareholder Activism and SEC Reporting Requirements" (2006) 57 Syracuse L. Rev. 63 at 66.

${ }^{65}$ CBCA, supra note 13 , ss. 137(5)(b.1).

66 See Shareholder Association for Research and Education, "Shareholder Resolution Database", online: $<$ http://www.share.ca/en/node/1432 $>$ and Fredericton Peace Coalition, "Maritime Human Rights Group Seeks

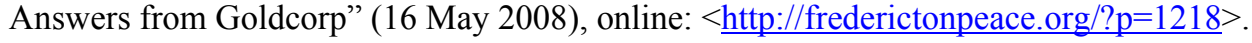

${ }^{67}$ Supra note 49.

${ }^{68}$ Coumans, supra note 59 at 2.
} 
...[T]he...proposal does not reflect the reality of life in our communities. The investors' concern for protection of our human rights remains solely at the level of concern. In the end, the...proposal allows for the sacking and destruction of our resources to continue without any regard for our health, life and territory or for any other aspects of the human rights of these ancient indigenous peoples.

...[H]uman rights have nothing to do with optimizing the profits of a transnational company that is sacking and destroying the resources of an ancient people. ${ }^{69}$

In negotiating this incongruity, it is important to remain mindful of the fact that socially responsible investment organizations utilizing the proposal mechanism must strive to make their proposals palatable to the receiving company on one hand and to their clients on the other. ${ }^{70}$ The former is especially important if the organization wishes to advance its cause via the dialogue process discussed above. This is presumably the case given that social/human rights-related proposals have a slim chance of adoption if put to a vote at a shareholder meeting. In fact, even if they receive a majority vote, the corporation is under no legal obligation to implement the recommendations of such a proposal. ${ }^{71}$

While addressing potential corporate involvement in human rights-violating activities is a goal of socially conscious shareholder proposals, this goal is pursued only under the overarching umbrella of financial risk reduction. As discussed, the governing legislative provisions arguably require the establishment of a financial connection. While I, of course, appreciate the two goals may very well exist in harmony, the fact that the interests of affected communities may conflict with those of proposing investors cannot be ignored. In the Goldcorp scenario, there is a clear divergence in interests; investor risk mitigation on one hand, juxtaposed against Guatemalan communities' desire to end the firm's subsidiary operations altogether. ${ }^{72}$ To date, the investor membership of the impact assessment Steering Committee has been dismissive of the latter ambition and startlingly paternalistic:

...[The] Marlin mine is a reality that is not going to go away. It is extremely unlikely the Guatemalan government will revoke the mining license and, most certainly, Goldcorp Inc. will not voluntarily close up shop and vacate the premises. Given that reality, the matter of determining and resolving the current social and environmental impacts on the population remains unaddressed and unresolved. In the judgement of the responsible investor group...the most

\footnotetext{
${ }^{69}$ ADISMI et. al., supra note 62.

${ }^{70}$ Coumans, supra note 59 at 2.

${ }^{71}$ Dhir, "Realigning", supra note 10 at 406, 402 (citations omitted).

72 ADISMI et. al., supra note 62 ("We will demand that the company be closed down and not be given the opportunity to continue polluting and destroying the lands of this ancient people").
} 
appropriate means to address those impacts - the real issues the people and communities are experiencing every day - is a human rights impact assessment. ${ }^{73}$

\section{SITUATING THE ISSUE WITHIN TWAIL DISCOURSE}

In a situation of direct conflict, the interests of locally affected communities must be respected. In that regard, while I have noted that the investor-firm dialogue process may prove educational for management in terms of the human rights-related impacts of business operations, there is also much to be learned by socially responsible investment organizations as they continue to employ the proposal mechanism in the post-CBCA amendment period. In particular, as they journey further into human rights terrain, they must familiarize themselves with relevant human rights discourses.

Despite its lack of acknowledgement in more conventional, prevailing literature, ${ }^{74}$ TWAIL provides both theoretical and methodological tools for dissecting transnational dynamics. ${ }^{75}$ As an intellectual movement, it has been described as "a broad dialectic (or large umbrella) of opposition to the generally unequal, unfair, and unjust character of an international legal regime that...helps subject the Third World to domination, subordination, and serious disadvantage."76

TWAIL scholarship is still evolving and, correspondingly, various substantive areas remain unexplored. ${ }^{77}$ To date, the intersections of TWAIL-related concerns and corporate law

73 "A Summary of Issues Relevant to the Human Rights Impact Assessment (HRIA) of Marlin Mine, Guatemala”
(February 2009) at 6 [emphasis added], online:

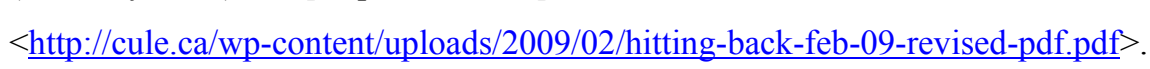

74 A. F. Sunter, "TWAIL as Naturalized Epistemological Inquiry" (2007) 20 Canadian Journal of Law and Jurisprudence 475 at 476 ("There is almost no recognition of TWAIL in mainstream scholarship").

${ }^{75}$ O.C. Okafor, "Critical Third World Approaches to International Law (TWAIL): Theory, Methodology, or Both?” (2008) 10 International Community Law Review 371 [Okafor, "Critical”].

76 O.C. Okafor, "Newness, Imperialism, and International Legal Reform in Our Time: A TWAIL Perspective" (2005) 43 Osgoode Hall Law Journal 171 at 176 (citation omitted). It is beyond the scope of this chapter to provide a complete picture of TWAIL-related scholarship. For a very limited sample, see Makau W. Mutua, Human Rights: A Political and Cultural Critique (Philadelphia: University of Pennsylvania Press, 2002), Makau Mutua, "What is TWAIL?" (2000) 94 American Society of International Law Proceedings 31, James Thuo Gathii, "Rejoinder: TWAILing International Law" (2000) 98 Michigan Law Review 2066, Anthony Anghie, Imperialism, Sovereignty and the Making of International Law (Cambridge: Cambridge University Press, 2004); B.S. Chimni, "Third World Approaches to International Law: A Manifesto" (2006) 8 International Community Law Review 3, Balakrishnan Rajagopal, International Law from Below: Development, Social Movements and Third World Resistance (Cambridge: Cambridge University Press, 2003).

${ }^{77}$ See J. Kangave, “'Taxing' TWAIL: A Preliminary Inquiry into TWAIL's Application to the Taxation of Foreign Direct Investment" (2008) 10 International Community Law Review 389 at 391 ("there is hardly any TWAIL 
have not formed the subject of scholarly inquiry. Similar to areas such as taxation, this is understandable when considering that corporate law and policy is often deliberated at the domestic - rather than the transnational - level. However, as discussed above, the effects of a Western state's corporate law provisions may be experienced far beyond the domestic realm and thus have the potential to assume a transnational character insofar as they impact on citizens of the Third World. ${ }^{78}$ In that respect, the relationship between the shareholder proposal mechanism and human rights abroad engages a fundamental organizing question posed by Anghie: "How does a particular rule or legal regime empower or disempower people in the Third World?"79

Mutua argues that contemporary human rights advocacy and discourse is characterized by a "damning metaphor" consisting of savages, victims and saviors. ${ }^{80}$ He asks human rights actors to engage in a process of critical self-reflection ${ }^{81}$ and cautions against perpetuating the image of agency-lacking victims ${ }^{82}$ who are rescued by Western saviors operating upon the tenants of liberalism. ${ }^{83}$ Despite good intentions, there is a real danger of replicating the dominant/submissive binary of the colonial encounter. ${ }^{84}$

The act of Western, human rights-concerned shareholders submitting a proposal that may affect local communities in the Third World country of business operations, followed by an investor-corporation MOU that does not contemplate representation from affected communities on the body overseeing an impact assessment process, falls squarely within the metaphor that Mutua impugns. The Goldcorp situation arguably has the potential to perpetuate power differentials, fortify race hierarchies ${ }^{85}$ and undermine the goals of autonomy and selfdetermination. Further, for those of us who identify with communitarian or so-called "progressive corporate law" scholarship, it runs the risk of qualifying the possible contribution of corporate law to the overall human rights project and of replicating the failures of other seemingly well-intentioned discourses, such as development. ${ }^{86}$

literature exploring the relationship between the Westphalian civilising mission and taxation") and I. T. Odumosu, "Challenges for the (Present/) Future of Third World Approaches to International Law" (2008) 10 International Community Law Review 467 at $476-477$.

${ }^{78}$ Kangave, ibid. at 391, 392 (citations omitted).

${ }^{79}$ A. Anghie, "TWAIL: Past and Future" (2008) 10 International Community Law Review 479 at 480.

${ }^{80}$ Makau W. Mutua, "Savages, Victims, and Saviors: The Metaphor of Human Rights" (2001) 42 Harvard International Law Journal 201 at 201.

${ }^{81}$ Ibid. at 202.

${ }^{82}$ Ibid. at 203.

${ }^{83}$ Ibid. at 204.

${ }^{84}$ Ibid.

${ }^{85}$ Ibid. at 207.

${ }^{86}$ R. Buchanan, "Writing Resistance Into International Law" (2008) 10 International Community Law Review 445 at 447. 
TWAIL-centered approaches focus on "global processes of marginalization and domination that impact on the lives and struggles of third world peoples." ${ }^{\circ 7}$ An investment activism strategy that is informed by TWAIL-discourse would take great pains not to hinder the advocacy efforts of locally affected communities. ${ }^{88}$ To be clear, I do not mean to suggest that overarching investor concerns of risk mitigation will necessarily run counter to these advocacy efforts; rather, that the potential for dissonance exists. In order to avoid such conflict, Western shareholders of transnational corporations must engage in a process of critical internal analysis in an effort to formulate an investment blueprint that is mindful of its own constraints, does not exploit power dynamics and is credible and inclusive from the perspective of those who will be directly affected by it. ${ }^{89}$ Such an approach would not consist of "an uncritical privileging of stories of essentialised Third World peoples", but would involve a significant, mindful examination of how the shareholder proposal contemplated "relates to human suffering in particular places." 90

In undertaking their own reflexive "assessment process" going forward, shareholders must give specific consideration to whether the proposal contemplated has the potential to impact local communities and to frustrate their stated political objectives. At a minimum, this would include consulting with these communities in the design of a shareholder proposal, ensuring community representation on bodies overseeing any impact assessment initiatives and ensuring prior free and informed consent. Anything less threatens the legitimacy of the proposal/impact assessment process ${ }^{91}$ and serves to perpetuate the "civilizing mission". 92 Indeed, the response of the impact assessment Steering Committee's investor membership to concerns regarding the assessment process is replete with 'civilizing' discourse, presuming that its "judgement" can best identify "the most appropriate means to address... the real issues the people and communities are experiencing every day." 93

${ }^{87}$ TWAIL Vision Statement, as quoted in Karin Mickelson, "Taking Stock of TWAIL Histories" (2008) 10 International Community Law Review 355 at 357.

${ }^{88} \mathrm{I}$, of course, do not mean to suggest that TWAIL voices are a monolith. Rather, they are varied and address a range of interests, but are also connected by a "unifying core". Okafor, "Critical", supra note 75 at 375 - 376.

${ }^{89}$ Anghie notes that such a self-reflective process is essential for the TWAIL movement itself:: "TWAIL scholarship...needs to be self-critical, aware of the limitations of its own analytic framework, and the voices it has excluded and suppressed." A. Anghie, "What is TWAIL: Comment" (2000) 94 American Society of International Law Proceedings 39.

${ }^{90}$ Pooja Parmar, "TWAIL: An Epistemological Inquiry" (2008) 10 International Community Law Review 363 at 365 (citation omitted).

${ }^{91}$ For a similar point, in the context of unilateral home state regulation of corporate activity, see S. L. Seck, "Unilateral Home State Regulation: Imperialism or Tool for Subaltern Resistance?" (2008) 46 Osgoode Hall Law Journal 565 at 601 ("the legitimacy of unilateral home state regulation is likely to be greater if the structure of the regulation gives voice to [subaltern] communities").

${ }^{92}$ This term is employed by numerous academics writing from a TWAIL perspective to "refer to the different methods employed by the West to justify intervention in the affairs of Non-western societies/"the Other"." See Kangave, supra note 77 at 390, n. 6 (citation omitted).

${ }^{93}$ Supra note 73. 
A TWAIL-versed plan of action would recognize and respect enduring community struggles that are undertaken with great peril. ${ }^{94}$ It would entail establishing continuing linkages with local civil society groups and not only conducting on-the-ground consultations with stakeholders (as done by the consortium), ${ }^{95}$ but ensuring that investment initiatives concerning local communities (and necessitating their involvement) have community support and a role for long-term community oversight. In addition to confirming local legitimacy, such efforts will prevent transnational firms from agreeing to the course of action suggested in a shareholder proposal merely in order to temporarily ease the pressures of human rights-related advocacy and to simultaneously reap the benefits of positive publicity. ${ }^{96}$

I am not arguing that shareholder proposals must always actively advance community desires. For example, it is legitimate for a proposal to seek a report from the company investigating and articulating potential human rights-related risks associated with Third World operations. Such a proposal does not call on the firm to cease operations altogether and, as such, may not reflect the demands of local stakeholders. However, unlike the consortium's proposal, it does not thwart the advancement of those demands, require local community participation or exclude local communities from supervising processes that directly impact them. In other words, it is a proposal that meets the simple, but essential test of "do[ing] no harm." ${ }^{.97}$ On this point, I appreciate and agree with MiningWatch's concern that proposals which are seemingly innocuous can actually have detrimental repercussions. However, I see this example as different from the ones it references (e.g. commissioning reports measuring project backing, enhancing methods of local consultation etc.), which are more conducive to allowing target corporations to simply bask in the light of reputational advancement. ${ }^{98}$ Most importantly, as a general rule, if a particular project has garnered noteworthy levels of community resistance, rights-concerned investors should be reticent to submit a proposal which may run antithetical to communities' stated goals. ${ }^{99}$

\section{CONCLUDiNg REMARKS}

The aftermath of the consortium's proposal reflects many of the problems identified above. Guatemala's Catholic Church has begun a rival impact assessment process, viewed as

\footnotetext{
${ }^{94}$ Coumans, supra note 59 at 2.

${ }^{95}$ Supra note 50.

${ }^{96}$ Coumans, supra note 59 at 2.

${ }^{97}$ Ibid. at 3.

${ }^{98}$ Ibid.

${ }^{99}$ Ibid.
} 
more inclusive and independent. Noted human rights scholar Douglas Cassel is collaborating with the Church after refusing to participate in the consortium/Goldcorp process on account of concerns relating to its independence. ${ }^{100}$ Further, the Public Service Alliance of Canada Staff Pension Fund, an original consortium member, recently withdrew from the process citing inter alia the absence of informed consent on the part of local indigenous peoples. ${ }^{101}$

In some respects, the removal of the previously enumerated CBCA restrictions, and the increased use of the proposal mechanism in the post amendment period, can be seen as part of a broader movement towards a reflexive, "new governance" approach. Given the constraints of traditional regulatory models and conventional legal frameworks, the new governance project seeks, in part, to transcend traditional punitive/deterrence-based measures ${ }^{102}$ and to focus instead on norm generation and the enhancement of "internal self-regulatory capacities". ${ }^{103}$ While this may not involve the direct regulation of corporate conduct with societal implications, ${ }^{104}$ part of the goal is to empower non-governmental actors (such as shareholders). In that respect, the approach is participatory and democratic, involving an important role for multiple societal segments. ${ }^{105}$

While these are laudable objectives, I am also mindful of the embeddedness discussion that begins this chapter and am uneasy with some of the new governance literature that seems to celebrate the notion of the decentred state. ${ }^{106}$ Seck cautions that when the state puts itself on the

${ }^{100}$ Correspondence from Catherine Coumans, MiningWatch Canada to the consortium et. al. (16 March 2009) at 1, online:

$<\underline{\text { http://www.rightsaction.org/articles/Goldcorp_ongiong_concern_32409.html }}>$.

${ }^{101}$ Bill Law, "Canada Goldmine Worries Grow” BBC News (30 March 2009), online:

$<$ http://news.bbc.co.uk/2/hi/americas/7968888.stm $>$

102 David Hess, "Social Reporting and New Governance Regulation: The Prospects of Achieving Stakeholder Accountability through Transparency" (2007) 17:3 Business Ethics Quarterly 453 at 453 [Hess, "New Governance Regulation"].

${ }^{103}$ Orly Lobel, "The Renew Deal: The Fall of Regulation and the Rise of Governance in Contemporary Legal Thought” (2004) 89 Minnesota Law Review 342 at 365. See also Bradley C. Karkkainen, “"New Governance” In Legal Thought and in the World: Some Splitting as Antidote to Overzealous Lumping" (2004) 89 Minnesota Law Review 471 at 473 ("This scholarship endeavors simultaneously to chronicle, interpret, analyze, theorize, and advocate a seismic reorientation in both the public policymaking process and the tools employed in policy implementation. The valence of this reorientation...is generally away from the familiar model of command-style, fixed-rule regulation by administrative fiat, and toward a new model of collaborative, multi-party, multi-level, adaptive, problem-solving New Governance.”).

${ }^{104}$ David Hess, "Public Pensions and the Promise of Shareholder Activism for the Next Frontier of Corporate Governance: Sustainable Economic Development" (2007) 2:2 Virginia Law and Business Review 221 at 234.

${ }^{105}$ Hess, "New Governance Regulation", supra note 102 at 455.

${ }^{106}$ Adam Crawford, "Networked Governance and the Post-Regulatory State?” (2006) 10:4 Theoretical Criminology 449 at 458 ("I believe it would be foolish to 'throw out the state' with the governance or governmentality bath water...we should not get carried away with 'a giddy sense at the moment among many intellectuals that the state is

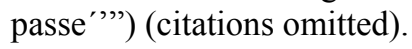


same footing as other interested parties, there is a risk that it will abdicate its governmental responsibilities. ${ }^{107}$ This concern is especially consequential when dealing with situations where there is an imbalance of power amongst stakeholders. There is the danger, for example, that global corporations (or, in this case, corporations acting in concert with activist investors) will usurp processes and unduly influence corporate accountability discourse. ${ }^{108}$

Along these lines, there could be an important role for the state to play in overseeing the proposal process and ensuring its equity. ${ }^{109}$ While I appreciate that an essential component of the TWAIL project is unpacking the traditional centrality of the state, I also note that the state "is not dismissed" 110 and that TWAIL literature does not abandon the idea of statehood in its entirety. ${ }^{111}$ As argued by Chimni, "there is the lack of a "public" voice in the emergence of corporate law without a State." $" 12$ Elsewhere, I have argued in favour of the establishment of an ad-hoc review panel. ${ }^{113}$ While there appears to be little political will for such a panel, I see a possible role for the "Office of the Extractive Sector CSR Counsellor" recently created by the Canadian government, though I admittedly view this Office as largely impotent given its inability to issue compulsory recommendations or conduct formal mediations. ${ }^{114}$

Shareholder proposals provide a useful lens through which to view the embeddedness of economic behaviour in social relations. As socially responsible investment organizations move forward with their advocacy, they must develop fluency in relevant human rights discourses such as TWAIL and must ensure that the processes they advocate are legitimate and inclusive vis-à-vis locally affected communities and do not undermine their stated political goals.

107 S. L. Seck, "Home State Responsibility and Local Communities: The Case of Global Mining" (2008) 11 Yale Human Rights \& Development Law Journal 177at 184, n. 35 (citations omitted).

108 John M. Conley \& Cynthia A. Williams, "Engage, Embed, and Embellish: Theory Versus Practice in the Corporate Social Responsibility Movement" (2005) 31 Journal of Corporation Law 1 at 36 (citation omitted).

109 “...[T]

${ }^{110}$ Buchanan, supra note 86 at 447.

${ }^{111}$ Kangave, supra note 77 at 397 (citation omitted).

${ }^{112}$ Chimni, supra note 76 at 13.

${ }^{113}$ Dhir, "Realigning", supra note 10 at $401-402$.

${ }^{114}$ Government of Canada, "Building the Canadian Advantage: A Corporate Social Responsibility (CSR) Strategy for the Canadian International Extractive Sector" (March 2009) at 10 - 11, online:

$<$ http://www.international.gc.ca/trade-agreements-accords-commerciaux/assets/pdfs/CSR-March2009.pdf $>$. The creation of this Office is a particular disappointment given the recommendations of the Advisory Group Report arising from the "National Roundtables on Corporate Social Responsibility and the Canadian Extractive Industry in Developing Countries". Among other measures, the report recommends the creation of an ombudsman's position and a tripartite Compliance Review Committee with more far-ranging capabilities. Supra note 51 at vi - vii. 